\title{
Testing hypotheses of the cause of peripheral thinning of the Greenland Ice Sheet: is land-terminating ice thinning at anomalously high rates?
}

\author{
A. Sole ${ }^{1}$, T. Payne ${ }^{1}$, J. Bamber ${ }^{1}$, P. Nienow ${ }^{2}$, and W. Krabill ${ }^{3}$ \\ ${ }^{1}$ Bristol Glaciology Centre, School of Geographical Sciences, Bristol, BS8 1SS, UK \\ ${ }^{2}$ School of Geosciences, University of Edinburgh, Drummond Street, Edinburgh, EH8 9XP, UK \\ ${ }^{3}$ Cryospheric Sciences Branch, Code 614.1, NASA Goddard Space Flight Center, Wallops Flight Facility, Wallops Island, \\ Virginia 23337, USA
}

Received: 25 July 2008 - Published in The Cryosphere Discuss.: 18 August 2008

Revised: 1 December 2008 - Accepted: 5 December 2008 - Published: 16 December 2008

\begin{abstract}
Recent observations have shown that the periphery of the Greenland ice sheet (GrIS) is thinning rapidly and that this thinning is greatest around marine-terminating outlet glaciers. Several theories have been proposed which provide a link between climate and ice thinning. We present surface elevation change $(d h / d t)$ data from NASA's Program for Arctic Regional Climate Assessment (PARCA) laser altimetry surveys for fourteen and eleven of the largest outlet glaciers in Southern Greenland from 1993 to 1998 and 1998 to 2006 respectively to test the applicability of these theories to the GrIS.

Initially, outlet glacier $d h / d t$ data are compared with data from concurrent surveys over inland ice (slow flowing ice that is not obviously draining into an outlet glacier) to confirm the effect of ice flow on surface thinning rates. Landterminating and marine-terminating outlet glacier $d h / d t$ data are then compared from 1993 to 1998 and from 1998 to 2006. Finally, ablation anomalies (the difference between the "normal" ablation rate from 1970 to 2000 and the ablation rate in the time period of interest) calculated with a positive degree day model are compared to both marine-terminating and land-terminating outlet glacier $d h / d t$ data.

Our results support earlier conclusions that certain marineterminating outlet glaciers have thinned much more than land-terminating outlet glaciers during both time periods. Furthermore we show that these differences are not limited to the largest, fastest-flowing outlet glaciers - almost all marine-terminating outlet glaciers are thinning more than land-terminating outlet glaciers. There was a four fold increase in mean marine-terminating outlet glacier thinning
\end{abstract}

Correspondence to: A. Sole

(a.j.sole@bristol.ac.uk) rates below $1000 \mathrm{~m}$ elevation between the periods 1993 to 1998 and 1998 to 2006, while thinning rates of landterminating outlet glaciers remained statistically unchanged. This suggests that a change in a controlling mechanism specific to the thinning rates of marine-terminating outlet glaciers occurred in the late 1990s and that this change did not affect thinning rates of land-terminating outlet glaciers.

Thinning rates of land-terminating outlet glaciers are statistically the same as ablation anomalies, while thinning rates of marine-terminating outlet glaciers are not. Thinning of land-terminating outlet glaciers therefore seems to be a response to changes in local mass balance (principally increases in air temperature) while thinning of marineterminating outlet glaciers is principally controlled by ice dynamics. The mechanism by which this dynamic thinning occurs is still not clear although its association with marineterminating outlet glaciers suggests perturbations at marine termini (calving) as the likely cause.

\section{Introduction}

The Greenland Ice Sheet (GrIS) is losing mass from its periphery through increased surface melting (Abdalati et al., 2001) and increased ice discharge into the surrounding ocean (Rignot and Kanagaratnam, 2006). Recent airborne altimetry observations show that the greatest thinning (and mass loss) is along fast flowing marine-terminating outlet glaciers where rates often exceed $10 \mathrm{~m} \mathrm{yr}^{-1}$ (Abdalati et al., 2001; Krabill et al., 2004). Between 1996 and 2005 the 21 largest outlet glaciers accelerated on average by $57 \%$ (Rignot and Kanagaratnam, 2006) while mass loss from the ice sheet increased from $91 \pm 31 \mathrm{~km}^{3}$ ice/year to $224 \pm 41 \mathrm{~km}^{3}$

Published by Copernicus Publications on behalf of the European Geosciences Union. 
ice/year, and its contribution to sea level rise increased from $0.23 \pm 0.08 \mathrm{mmyr}^{-1}$ to $0.57 \pm 0.1 \mathrm{mmyr}^{-1}$.

The rapid thinning of some GrIS marine-terminating outlet glaciers has been attributed to changes in ice dynamics as well as rising temperatures since thinning rates exceed those expected from changes in surface mass balance alone (Abdalati et al., 2001). Dynamic thinning is defined as $D=(U \partial H / \partial x)-H E_{Z}$ where $D$ is dynamic thinning, $U$ is the depth averaged horizontal velocity, $\partial H / \partial x$ is the icethickness gradient taken along the direction of ice flow, $H$ is the ice thickness and $E_{Z}$ is the depth-averaged vertical creep rate (Thomas et al., 2003). Dynamic thinning occurs when an outlet glacier accelerates beyond the velocity necessary for ice flux to balance net accumulation within its basin. Ice dynamics are currently thought to account for about half of GrIS mass loss and contribution to sea level rise (Rignot and Kanagaratnam, 2006). For three of the GrIS's largest marine-terminating outlet glaciers (Helheim Gletscher, HG; Kangerdlugssuaq Gletscher, KG; and Jakobshavn Isbrae, JI) these changes in ice dynamics are thought to have been caused by perturbations at the calving front due to climate induced thinning of their termini (Abdalati et al., 2001; Howat et al., 2007). However, it is not yet clear to what extent calving is responsible for the thinning and acceleration of other GrIS marine-terminating outlet glaciers (Krabill et al., 2004).

The lubricating effect of increased surface meltwater reaching the bed of the ice has also been cited as a possible mechanism for climate induced dynamic thinning (Zwally et al., 2002). Such a mechanism would presumably be applicable to regions of both land and marine-terminating ice. Parizek and Alley (2004) used the findings of Zwally et al. (2002) to link basal sliding with the volume of surface melt on annual timescales in a predictive model of GrIS evolution under increased atmospheric $\mathrm{CO}_{2}$ concentrations. They found that the link leads to a positive feedback: meltinduced sliding thins and flattens the ice sheet periphery, enlarging the area experiencing surface melting and sliding, and allowing this area to expand inland over time (Parizek and Alley, 2004). Understanding the relative importance of calving front retreat and meltwater lubrication on ice dynamics, and their link to climate change is therefore crucial to our ability to make century-scale predictions of the GrIS because meltwater-induced dynamic thinning will be ongoing as long as surface melt continues to increase, while calving-induced thinning will cease once the ice sheet margin retreats beyond direct contact with the ocean.

Here we use laser altimeter data from NASA's Program for Arctic Regional Climate Assessment (PARCA) to update existing surface elevation change data (the 2006 data is previously unpublished) and to directly compare thinning rates for inland ice and fourteen and eleven marine and landterminating outlet glaciers in southern Greenland from 1993 to 1998 and 1998 to 2006 respectively. We begin by describing the calving and meltwater dynamic thinning theories in more detail before going on to make, test and discuss several hypotheses to further investigate the causes of GrIS dynamic thinning.

\subsection{Dynamic thinning mechanisms}

Two principal mechanisms for climate induced dynamic thinning of outlet glaciers have been presented in the literature. The first suggests that enhanced ice melt caused by climatic warming is affecting ice dynamics directly (Zwally et al., 2002). Longer and more widespread surface melt may increase drainage to the bed and thus enhance ice flow through basal lubrication. Zwally et al. (2002) found that seasonal periods of ice acceleration and deceleration $(\sim 10 \%$ above the average annual velocity) coincided with the onset and cessation of increased local surface melting in an area of slow moving ice at Swiss Camp, $\sim 35 \mathrm{~km}$ from the ice sheet margin, just north east of JI.

Observations on John Evans Glacier, a predominantly cold valley glacier located on the east coast of Ellesmere Island, Arctic Canada, suggest that hydrologically-driven propagation of fractures may provide a mechanism by which surface water can reach the bed on relatively short time periods (Boon and Sharp, 2003). However, the ice at John Evans Glacier where fracturing was inferred, is only $\sim 150 \mathrm{~m}$ thick whereas ice thickness at Swiss Camp is $\sim 1000 \mathrm{~m}$. Although theoretically possible, crack propagation through $\sim 1000 \mathrm{~m}$ of ice requires an initial crevasse which is tens of meters deep, a constant supply of water (for example from a supraglacial lake) and abnormally high deviatoric stresses to allow the fracture to propagate (Alley et al., 2005). van der Veen (2007) found that theoretically, cracks will propagate to the full ice thickness as long as they have a constant supply of water and the rate of propagation remains greater than the rate of refreezing. Crack propagation is controlled primarily by the rate of water injection and crevasses could penetrate $\sim 1000 \mathrm{~m}$ of ice on a timescale of hours to days provided there is a sufficient water supply (van der Veen, 2007).

Large melt-water ponds ( $\sim 5 \mathrm{~km}$ diameter) form on the ice sheet surface during the melt season and some of these ponds are known to drain very rapidly on a time scale of hours (Box and Ski, 2007). If such a large, rapid influx of water reaches the bed, changes in the configuration of the subglacial drainage system and subsequent reductions in basal traction could cause ice acceleration (McMillan et al., 2007; Sneed and Hamilton, 2007). A similar process is thought to be responsible for short lived speed-ups observed on many Alpine glaciers (Mair et al., 2001) and has been linked to velocity variations of an Arctic glacier (Bingham et al., 2005).

The relationship between surface melt and ice velocity is however not a simple one (Kamb, 1987; Truffer et al., 2005). In Alpine systems speed-ups are generally short-lived as the subglacial drainage system quickly adapts to the larger influx of surface water. Recent evidence suggests that the subglacial drainage system under parts of the GrIS may be similarly efficient (Das et al., 2008). 
Although lake drainage events have been shown to increase local ice velocities over short $(24 \mathrm{~h})$ time periods (Das et al., 2008), outlet glaciers seem to be insensitive to direct input of meltwater to the bed over longer time periods (Echelmeyer and Harrison, 1990). This lack of seasonal velocity variations is thought to be due to the majority of ice motion, at least for JI, being supplied by deformation of a thick $(\sim 300 \mathrm{~m})$ layer of softer, temperate ice at the glacier bed, rather than by basal sliding or a deforming sediment layer (Clarke and Echelmeyer, 1996; Funk et al., 1994; Luthi et al., 2002). Also, current summer accelerations of marine-terminating outlet glaciers in west Greenland represent speed-ups of less than $15 \%$ of their annual mean velocities (Joughin et al., 2008a). A notable exception to this insensitivity was a $\sim 300 \%, 7$ week speed up in 1995 of Ryder Gletscher in Northern Greenland which coincided with the drainage of several large supraglacial lakes (Joughin et al., 1996). The implication of such a direct link between surface meltwater and ice velocity is that the whole ice sheet margin may be sensitive to meltwater input on a variety of timescales, as dictated by local basal conditions and ice geometry.

The second mechanism for climatic induced dynamic thinning of outlet glaciers is related to the collapse of ice shelves and retreat of marine termini. Changes in flow of an outlet glacier occur in response to changes in its force balance the sum of gravitational and resistive forces acting on the ice (Payne et al., 2004). This theory has been applied successfully to outlet glaciers in West Antarctica (Payne et al., 2004; Schmeltz et al., 2002) where modeling exercises have found that the effects are felt up to $100 \mathrm{~km}$ from the grounding line (Payne et al., 2004). Accelerated flow at the glacier terminus causes "drawdown" and thinning of upstream ice which in turn increases flow to the terminus by reducing effective pressure at the bed (Meier and Post, 1987).

Between 1997 and 2001, the $15 \mathrm{~km}$ long floating tongue of JI retreated by $\sim 4 \mathrm{~km}$. A force perturbation analysis of this retreat (Thomas, 2004) suggests that the glacier's thinning and acceleration, probably caused initially by increased calving rates, was sustained by rapid melting $\left(\sim 80 \mathrm{~m} \mathrm{yr}^{-1}\right)$ of the remaining floating section of the glacier. For much of the GrIS, where marine-terminating glaciers have little or no floating ice tongue, a retreat of the calving front can produce a greater initial perturbation since there is a loss of both lateral and basal resistance (Bamber et al., 2007). This is thought to have been the case for HG and KG which have both retreated and accelerated significantly in recent years (Howat et al., 2005, 2007; Luckman et al., 2006). Neither of these glaciers have a significant floating section (Rignot et al., 2004), and retreat is thought to have been initiated by climatic induced thinning leading to floatation of lightly grounded, heavily crevassed ice near their snouts (Luckman et al., 2006). These retreats are thought to occur via a series of large, short-lived calving events apparently coincident with so-called "glacial earthquakes" (Joughin et al., 2008b).
The frequency of such "earthquakes", possibly caused by basal sliding of outlet glaciers, exhibits a strong seasonal cycle, and their overall frequency in Greenland doubled from 2001 to 2006 (Ekstrom et al., 2006).

The timing of changes in calving front position relative to ice velocity and surface elevation changes of $\mathrm{HG}$ and $\mathrm{KG}$ suggests that increased calving was the dominant cause of ice acceleration (Howat et al., 2005, 2007; Luckman et al., 2006), but how important calving has been in the retreat of other marine-terminating outlet glaciers is not clear. Calving has hitherto been considered to be controlled locally by factors such as fjord bathymetry and ice geometry (van der Veen, 2002). However, the apparent relative synchronicity of changes in claving front position, ice velocity and surface thinning between different outlet glaciers (Luckman et al., 2006) suggests a forcing which acts over large spatial scales, such as changes in the atmosphere or ocean (Krabill et al., 2004). A definitive causal link between climate and calving rates has not yet been established. If dynamic thinning is caused by calving perturbations at marine termini, it will be self-limiting, and would cease once the ice sheet retreats beyond direct contact with the ocean.

Marine-terminating outlet glaciers may be inherently more sensitive to changes in basal water pressure than landterminating outlet glaciers since their termini are often already at or near the flotation point. Therefore, an identical increase in surface meltwater input to the bed would be more likely to raise subglacial water pressure to values approaching overburden pressure across other areas of the bed at a marine-terminating terminus, with correspondingly larger ice acceleration and dynamic thinning. If this were the case, a surface melt induced forcing also has the potential to reduce significantly once the GrIS retreats beyond the ocean. However, there may also be other factors related to ice velocity, bed roughness and glacier geometry which serve to decrease marine-terminating outlet glaciers' sensitivity to variations in basal water pressure (Joughin et al., 2008a). Joughin et al. (2008), found that the seasonal summer ice acceleration for both "ice sheet" (ice velocity $<150 \mathrm{~m} \mathrm{yr}^{-1}$ ), and "outlet glacier" (ice velocity $>150 \mathrm{~m} \mathrm{yr}^{-1}$ ) regions on the west coast of the GrIS was fairly spatially consistent when averaged over 24 days. This suggests that dynamic thinning caused by ice acceleration is likely to be similarly uniform.

\subsection{Thinning hypotheses}

The applicability of these theories to our sample of Greenland outlet glaciers can be assessed by testing several hypotheses using PARCA laser altimetry data.

1.2.1 Hypothesis 1: thinning is not dynamic, but is related to local mass balance changes

Although ice dynamics are now widely accepted as a cause of ice thinning in Greenland, this is a null hypothesis which 


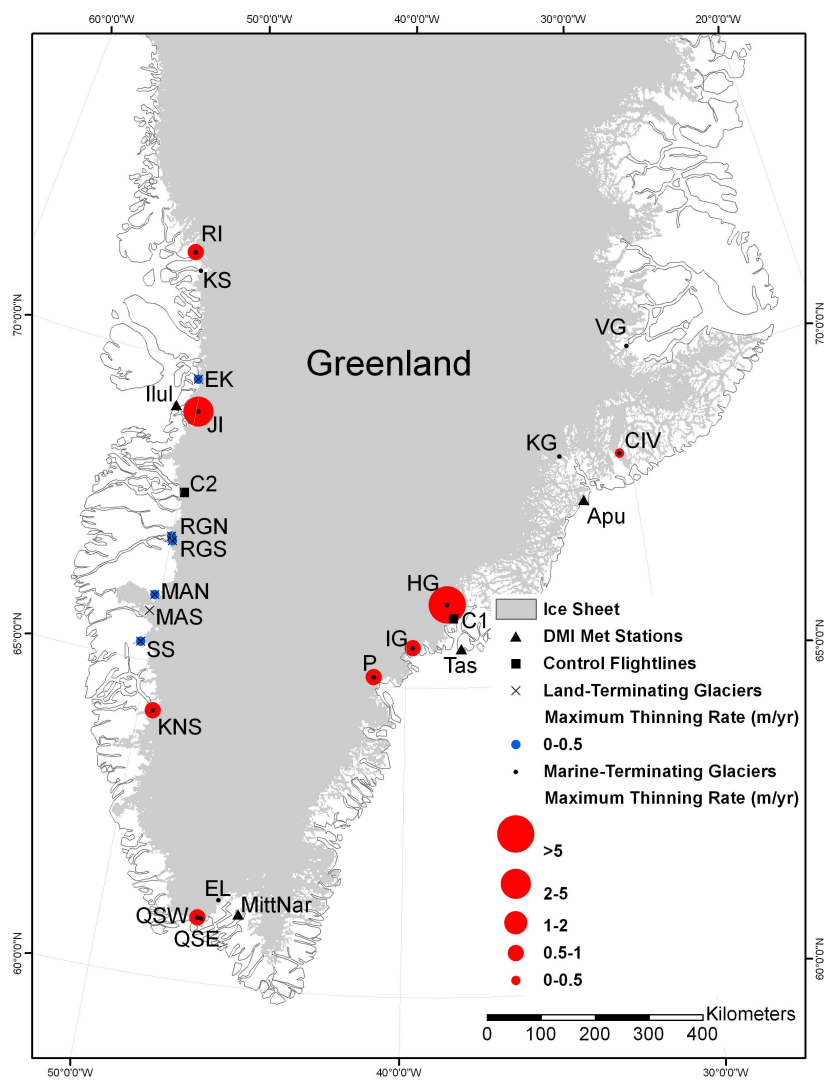

Fig. 1. Locations of glaciers and DMI Meteorological Stations mentioned in the text. The five digit number is the station's World Meteorological Organisation code. Also shown for all outlet glaciers with data is the maximum annual mean thinning rate (below $1000 \mathrm{~m}$ elevation) for the periods 1993 to 1998 and 1998 to 2006.

allows us to test whether "inland ice" (slow flowing ice that is not obviously part of an outlet glacier) and outlet glaciers are thinning at different rates. This hypothesis assumes that thinning varies only with local mass balance i.e. with altitude and between climatic regions. To test this hypothesis we compare ice surface elevation change rates for inland ice (the control flight line) with that of nearby outlet glaciers for two areas in Southern Greenland.

1.2.2 Hypothesis 2: thinning is principally caused by direct meltwater effects on ice flow

This is the first mechanism discussed in Sect. 1.1. It is uncertain whether marine and land-terminating glaciers will have the same sensitivity to increased meltwater at the bed. As previously mentioned, differences in effective pressures which favour an enhanced sensitivity for marine-terminating outlets may be countered by the effects of smooth beds, basal shear heating and the geometry characteristic of such outlet glaciers (Joughin et al., 2008a). A reasonable first assumption is therefore that $d h / d t$ of land-terminating and
Fig. 1. Continued.

\begin{tabular}{l|l}
\hline Marine-terminating Outlet Glaciers: & Land-terminating Outlet Glaciers: \\
\hline RI: Rink Isbrae & EK: Eqip Kuqssua \\
KS: Kangerdlugssup Sermerssua & RGN: Russel Glacier North \\
JI: Jakobshavn Isbrae & RGS: Russel Glacier South \\
KNS: Kangiata Nunata Sermia & MAN: Majoqqap Alanngua North \\
QSW: Qaleragdlit Sermia West & MAS: Majoqqap Alanngua South \\
QSE: Qaleragdlit Sermia East & SS: Sarquap Sermia \\
EL: Eqaluit Lluat & \\
P: Pikiutdleq & \\
IG: Ikerssuaq Gletscher & \\
HG: Helheim Gletscher & \\
KG: Kangerdlugssuaq Gletscher & \\
CIV: Cristian IV Gletscher & \\
VG: Vetsfjord Gletscher & Control Flight lines: \\
\hline DMI Meteorological Stations: & C1: Control flight line 1 \\
\hline Ilul: Ilulissat (Lufthavn) 04216 (04221) & C2: Control flight line 2 \\
MittNar: Mittarfik Narsarsuaq 04270 & \\
Tas: Tasillaq 04360 & \\
Apu: Aputiteeq 04351 &
\end{tabular}

marine-terminating outlet glaciers should be statistically the same. We test this hypothesis by comparing mean $d h / d t$ for a number of marine-terminating and land-terminating outlet glaciers in Southern Greenland (Fig. 1 and Tables 1 and 2). This region was chosen because there are more marineterminating and land-terminating outlet glaciers with good flight line coverage.

1.2.3 Hypothesis 3: thinning of marine-terminating outlet glaciers is due to calving front retreat and thinning on land-terminating ice is due to surface mass balance

In this case land-terminating outlet glaciers should be thinning at a rate related to increases in the number of Positive Degree Days (PDDs), while thinning rates of marineterminating outlet glaciers should be significantly greater than those expected from changes in air temperature. This hypothesis is tested by comparing observed $d h / d t$ for landterminating and marine-terminating outlet glaciers with the melt expected from increases in air temperature using a PDD Model (Braithwaite, 1995).

\section{Data and methods}

\subsection{Ice surface elevation data}

Ice surface elevation data were acquired using NASA's Airborne Topographic Mapper (ATM). The ATM is a conicalscanning laser ranging system, which, with the aircraft $400 \mathrm{~m}$ above the ice surface, produces a swath of at least $140 \mathrm{~m}$ containing many $1 \mathrm{~m}$ footprints of surface elevation. These measurements have root mean square errors (RMSE) of $10 \mathrm{~cm}$ or better (Krabill et al., 2000). The ATM data were processed to a stage whereby each data point had a surface elevation (ellipsoid height) and a geographic location. Data 
Table 1. $d h / d t$ from 1993 to 1998: marine-terminating outlet glaciers used in this analysis: KS, RI, IG, P, CIV, KG, HG, KNS, QSW, EL and JI. Land-terminating outlet glaciers used in this analysis: SS, RGS, RGN, MAS, MAN and EK. These are mean values for both sides of each flightline and for the elevation ranges shown (refer to Fig. 1 for locations). Units are $\mathrm{m} \mathrm{yr}^{-1}$.

\begin{tabular}{lccccccccccccccccc}
\hline & KS & RI & IG & P & CIV & KG & HG & KNS & QSW & EL & JI & SS & RGN & RGS & MAS & MAN & EK \\
\hline $\begin{array}{l}\text { Mean } d h / d t \\
<1000 \mathrm{~m}\end{array}$ & -0.85 & -0.03 & -0.55 & -1.80 & -0.49 & - & - & -1.30 & -1.16 & - & 0.45 & 0.28 & -0.14 & -0.15 & - & -0.35 & -0.22 \\
$\begin{array}{l}\text { Max thin } \\
<1000 \mathrm{~m}\end{array}$ & -1.66 & -0.51 & -1.01 & -2.05 & -0.72 & - & - & -1.30 & -1.16 & - & 0.15 & -0.02 & -0.14 & -0.15 & - & -0.18 & -0.23 \\
$\begin{array}{l}\text { Mean } d h / d t \\
>1000 \mathrm{~m}\end{array}$ & 0.07 & - & -0.23 & -0.37 & - & -0.51 & -0.10 & -0.22 & -0.24 & -0.23 & 0.02 & 0.12 & -0.12 & -0.04 & 0.03 & -0.03 & - \\
$\begin{array}{l}\text { Max thin } \\
>1000 \mathrm{~m}\end{array}$ & 0.01 & - & -0.41 & -0.53 & -0.07 & -0.97 & -0.17 & -0.48 & -0.59 & -0.57 & -0.09 & 0.05 & -0.24 & -0.12 & -0.08 & -0.14 & - \\
\hline
\end{tabular}

Table 2. $d h / d t$ from 1998 to 2006: marine-terminating outlet glaciers used in this analysis: KS, RI, IG, CIV, KG, HG, QSW, VG and JI. Land-terminating outlet glaciers used in this analysis: SS and RGS. These are mean values for both sides of each flightline and for the

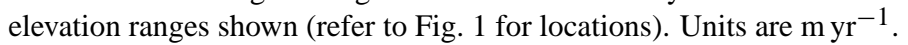

\begin{tabular}{lccccccccccc}
\hline & KS & RI & IG & CIV & KG & HG & QSW & VG & JI & SS & RGS \\
\hline $\begin{array}{l}\text { Mean } d h / d t \\
<1000 \mathrm{~m}\end{array}$ & 0.09 & -2.02 & -1.41 & -0.61 & - & -9.77 & -2.60 & -0.83 & -5.30 & -0.21 & -0.17 \\
$\begin{array}{l}\text { Max thin } \\
<1000 \mathrm{~m}\end{array}$ & -0.20 & -3.00 & -2.16 & -1.05 & - & -13.45 & -8.26 & -2.77 & -5.93 & -0.36 & -0.30 \\
$\begin{array}{l}\text { Mean } d h / d t \\
>1000 \mathrm{~m}\end{array}$ & - & -0.95 & -0.32 & -0.50 & -2.69 & -0.99 & -0.17 & -0.23 & -1.64 & -0.13 & 0.06 \\
$\begin{array}{l}\text { Max thin } \\
>1000 \mathrm{~m}\end{array}$ & - & -1.17 & -1.13 & -0.55 & -2.69 & -4.39 & -0.64 & -0.64 & -2.25 & -0.23 & -0.17 \\
\hline
\end{tabular}

were acquired for the period 1993 to 2006 with the number of individual flight lines during this time varying between outlet glaciers. Extensive systematic surveys of the outlet glaciers of Southern and Northern Greenland were carried out in 1993 to 1998 and 1994 to 1999 respectively. Subsequently, surveys were carried out on the most rapidly changing outlets with many of those in Southern Greenland being resurveyed in 2006, the results of which are previously unpublished. Only years with concurrent surveys could be used. There is a chance that a time interval of 5 to 8 years between elevation surveys may mean we miss changes in outlet glaciers which occur over shorter time periods (Howat et al., 2005; Luckman et al., 2006). However, we believe that our sampling is able to show the large scale spatial and temporal variations in outlet glaciers which affect the GrIS as a whole.

\subsection{Meteorological data}

Mean daily temperatures were calculated from the minimum and maximum daily surface air temperatures obtained from four coastal automatic weather stations operated by the Danish Meteorological Institute (DMI) (Fig. 1). Data are based on temperature measurements taken every $3 \mathrm{~h}$ according to standard World Meteorological Organisation guidelines whereby a thermometer is placed inside a radiation shield $2 \mathrm{~m}$ above ground (Cappelen et al., 2007). Tasillaq and Ilulissat stations have data extending from 1961 to 2006, and Aputiteeq and Mittarfik Narsarsuaq stations from 1961 to 2004. At Ilulissat, the station moved to the airport in 1991 but this is not thought to have significantly affected the homogeneity of the data (Cappelen et al., 2001). Years missing more than ten consecutive days were excluded. These data were used in a simple PDD model to estimate ablation anomalies which were then compared with observed surface elevation change rates as discussed in Sect. 2.4. Although it is possible that data from these coastal stations are not representative of prevailing conditions on the ice sheet, coastal meteorological stations have been used in many previous PDD analyses (Abdalati et al., 2001; Hanna et al., 2005, 2006; Hanna and Valdes, 2001; Thomas et al., 2003). Hanna et al. (2008:332), suggest that coastal "DMI data reflect changing meteorological conditions on the adjacent low-lying marginal ablation zone of the ice sheet, where much of the seasonal melt and subsequent runoff occurs".

2.3 Calculating and comparing ice surface elevation changes

The elevation and location data for each ATM output block were used to form a three dimensional Triangulated Irregular 
Network (TIN) representing the ice surface elevation along a particular flight line. Where flight lines from subsequent years overlap, elevations can be compared and a mean annual $d h / d t$ value for the intervening time period calculated. Mean $d h / d t$ was calculated for $100 \mathrm{~m}$ altitudinal bands for each flight line.

Initially, we compared $d h / d t$ for "inland ice" with nearby outlet glaciers in two regions in Southern Greenland (JI region and HG region) to test Hypothesis 1. In the JI region, comparisons were made for 2005 to 2006 between the control flight line and JI, Rink Isbrae (RI), and Kangerdlugssup Sermerssua (KS). RI and KS are smaller marine-terminating outlets situated to the north of JI (Fig. 1). In the HG region, comparisons were made for 1993 to 1998,1998 to 2001, 1998 to 2005, and 1998 to 2006 between the control flight line, HG and Ikerssuaq Gletscher (IG - a smaller marineterminating outlet to the south of $\mathrm{HG}$ ).

A similar exercise was undertaken to compare land and marine-terminating outlet glaciers (Hypothesis 2). For the purposes of this paper, land-terminating outlet glaciers are defined by their having balance velocities (Bamber et al., $2000 \mathrm{~b})$ greater than those of surrounding land-terminating ice, and are often constrained by bedrock topography. Surface elevation change rates were extracted from flight lines along outlet glaciers in Southern Greenland only. For the period 1993 to 1998, eleven ocean and six land-terminating outlets were used. For 1998 to 2006, nine marine-terminating and two land-terminating outlets were used (see Figs. 4 and 5 for which glaciers were used and Fig. 1 for their locations). Table 1 (1993 to 1998) and Table 2 (1998 to 2006) show $d h / d t$ data for all glaciers used in Hypothesis 2 . In order to increase sample size each side of the flight line was treated separately. The PARCA dataset is heavily weighted towards marine-terminating outlet glaciers (65\% of all surveyed outlets from 1993 to 1998 and 82\% from 1998 to 2006) as these have shown the most elevation change in the last decade (Krabill et al., 1999, 2000, 2004). However, we do not believe that this is an overly biased sample of the total population of outlet glaciers (estimated as $75 \%$ marine-terminating and 25\% land-terminating in Southern Greenland using data from The National Survey and Cadastre of Denmark's Topographic Atlas of Greenland).

PARCA flights were originally conducted to map areas showing greatest thinning so there are relatively few flights which cover slow moving ice near the margins of the ice sheet at an equivalent altitude to the outlet glaciers. Our two control flights may not be representative of thinning rates for all slow ice areas. However, Control 2 extends $\sim 100 \mathrm{~km}$ from North to South and so represents a large area of slow moving ice. Interpolation of laser altimetry data for the whole ice sheet (Krabill et al., 1999, 2000, 2004) shows that our control flights are broadly representative of thinning rates in other slow ice areas.

To compare the control flights to a range of marineterminating outlet glaciers, we chose three marine- terminating outlets that have retreated significantly (HG, JI and RI) and two that have retreated less (IG and KS). This selection is limited by proximity to, and coincidence with, the Control flight lines.

In order to directly compare marine-terminating and landterminating thinning rates, meltwater must be assumed to be equally available and likely to reach the bed in either a marine-terminating or land-terminating environment. For this to be the case, spatial density of moulins, supraglacial lakes and crevasses should be the same for marine-terminating and land-terminating outlets. A qualitative analysis of Landsat images (acquired in 2001) shows that lakes are equally distributed across marine-terminating and land-terminating regions along the western region of the ice sheet. Around HG and Control 1, there are fewer lakes due to steeper surface slopes.

Basal lubrication could be greater under marineterminating outlet glaciers due to meltwater being preferentially routed into the deep subglacial troughs typically associated with such outlets. Also, pronounced topography intensifies the geothermal heat flux in deep valleys and attenuates it on mountain tops. van der Veen et al. (2007) found that a subglacial trough such as that underlying Jakobshavn Isbrae can increase local geothermal heat flux by $100 \%$. This is unlikely to be sufficient to explain the observed rates of dynamic thinning and cannot explain time dependent changes in ice velocity and surface thinning.

\subsection{Comparing observed outlet glacier elevation change} with estimated melt

Finally, observed outlet glacier elevation changes were compared to melt anomalies calculated by a PDD model. Large differences indicate that there must be some other signal apart from enhanced ablation controlling thinning rates. Spatial patterns in the occurrence of such discrepancies may help to establish the relative importance of the dynamic thinning mechanisms discussed in Sect. 1.1. Flight lines from all available years and for as many outlet glaciers as possible were used to construct a comprehensive record of observed $d h / d t$.

For a glacier assumed to be in equilibrium, annual mass loss (through ablation and calving) is balanced by annual mass gain (through accumulation and ice inflow). Therefore to calculate the ablation contribution to $d h / d t$ observations, the "normal" ablation rate must be compared with that of the time period of interest to produce an ablation anomaly.

Mean daily air temperatures were used to calculate the number of PDDs for each glacier at sea level based on latitudinal temperature gradients from Hanna et al. (2005). Ablation was then estimated by multiplying this value by the Degree Day Factor (DDF). In the bare-ice zone, where all winter snow is removed by melting, snow and ice DDFs of $0.003 \mathrm{~m}$ and $0.008 \mathrm{~m}$ water $\mathrm{PDD}^{-1}$ (Braithwaite, 1995) and densities of $333 \mathrm{kgm}^{-3}$ and $917 \mathrm{kgm}^{-3}$ both translate 
to surface elevation changes of $0.009 \mathrm{mPDD}^{-1}$. These values are considered suitable for lower elevation regions of the ice sheet (Abdalati et al., 2001). Above the bare-ice zone, although the amount of snow and ice melt associated with PDDs remains the same, the amount of surface lowering varies depending on changes in firn compaction rate as well as melt rate. Firn compaction rate is related principally to surface air temperatures and therefore varies with the number of PDDs (Thomas et al., 2003). We use DDFs from Thomas et al. (2003) to correct our PDD derived $d h / d t$ data for firn compaction above the bare ice zone.

The number of summer month PDDs (May to September (Fettweis et al., 2007)) between subsequent flight lines were compared with the mean number of summer PDDs for the period 1970 to 2000 to estimate the ablation anomaly. The magnitudes of these anomalies were extrapolated inland assuming a linear decrease with surface elevation to zero at the inland limit of summer melting. This zero melt elevation is the same as that used by Abdalati et al. (2001) and is based on the melt distribution of Abdalati and Steffen (1997). Although recent observations of melt extent (Tedesco, 2007) show that the zero melt elevation has increased, the previously published distribution (Abdalati and Steffen, 1997) is deemed accurate enough for the purposes of this study. Where thinning occurred, the percentage of total observed thinning which could not be explained by the ablation anomaly (i.e. is caused by "dynamic" thinning) was calculated.

Calculating mean daily air temperature from minima and maxima is a well established method and has been used extensively on historic data with root mean square errors (RMSE) of $0.71^{\circ} \mathrm{C}$ per day (Dall'amico and Hornsteiner, 2006). Using our DDFs, this translates to a surface elevation change rate RMSE of $0.006 \mathrm{~m}$ per day. The magnitude of the differences between observed thinning rates for marineterminating outlet glaciers and those calculated by the PDD model are generally so large that errors associated with calculating daily mean temperatures in this way are considered acceptable for this study.

The PDD model does not include precipitation which can vary annually by up to $0.5 \mathrm{~m} \mathrm{yr}^{-1}$ in Southern Greenland (Hanna et al., 2006). The potential effects of inter-annual variations in precipitation are discussed in detail in Sect. 4.2. PDD models relate daily mean air temperatures above a certain threshold value (usually $0^{\circ} \mathrm{C}$ ) to ice and snow melt using an empirically defined DDF (Braithwaite, 1995). Although DDFs can be extremely variable, the values used here are considered appropriate for lower elevation regions of the ice sheet (Abdalati et al., 2001).

\section{Results}

In all following graphs, the $0-100 \mathrm{~m}$ elevation band can be ignored as changes in surface elevation here most likely represent changes in calving front position, the movement of large crevasses down-glacier and the passage of icebergs. Confidence limits in the text refer to the results of a paired $\mathrm{t}$-test between the two relevant populations.

3.1 Hypothesis 1: thinning is not dynamic, but is related to local mass balance changes: comparing inland ice and outlet glaciers

Surface elevation rates were compared for inland ice and outlet glaciers for two control areas - HG region (Control 1) and JI region (Control 2) (Fig. 1). The results are shown in Figs. 2 and 3 respectively. Mean $d h / d t$ values were calculated for $100 \mathrm{~m}$ elevation bands and then compared between flight lines.

In the HG region, from 1993 to 1998 both outlet glaciers and Control 1 thinned by a similar amount (between $0.5 \mathrm{~m} \mathrm{yr}^{-1}$ and $1.0 \mathrm{~m} \mathrm{yr}^{-1}$ at $200 \mathrm{~m}$ above sea level). This is also similar in magnitude to the $d h / d t$ rates calculated by the PDD model. Between 1998 and 2001, HG and Control 1 , above $1000 \mathrm{~m}$, thickened by 0.1 to $0.5 \mathrm{~m} \mathrm{yr}^{-1}$, while IG thickened by 0.5 to $1.0 \mathrm{~m} \mathrm{yr}^{-1}$. The ablation anomaly for this period was smaller than that for 1993 to 1998 which may account for the slight thickening of Control 1 . However in the lower reaches of $\mathrm{HG}$, observed thinning rates were more than double those predicted by the PDD model which suggests an alternative source than local changes in mass balance i.e. ice dynamics.

From 1998 to $2006 \mathrm{HG}$ thinned by more than $13.0 \mathrm{~m}$ in its lower reaches while the ablation anomaly for the same period suggests that thinning was approximately $1.0 \mathrm{~m}$. In the same period, IG thinned by about $2.0 \mathrm{~m}$ (twice the predicted ablation anomaly). The differences in mean $d h / d t$ values between the ablation anomaly and observed thinning at $\mathrm{HG}$ and IG are significant at the $99.9 \%$ and $99.0 \%$ confidence levels respectively. Observed thinning of Control 1 is similar to (though slightly less than) that predicted by the ablation anomaly suggesting that changes in surface elevation at this location are principally controlled by local mass balance.

In the JI region, between 2005 and 2006 JI thinned by $4.0 \mathrm{~m}$ near its calving front (Fig. 3). During the same time, Control 2 thinned by $<0.5 \mathrm{~m}$ at the same elevation. This difference is significant at the $99.0 \%$ confidence level. RI thinned by up to $1.0 \mathrm{~m}$ near its terminus (significant at the 90\% confidence level), while KS showed no obvious pattern of thinning at all and actually thickened near its calving front (Fig. 3). Unfortunately there are no temperature data from Ilulissat (the closest meteorological station) for a large part of the summer of 2006, so no comparison can be made between ablation anomalies and observed thinning for this period. 

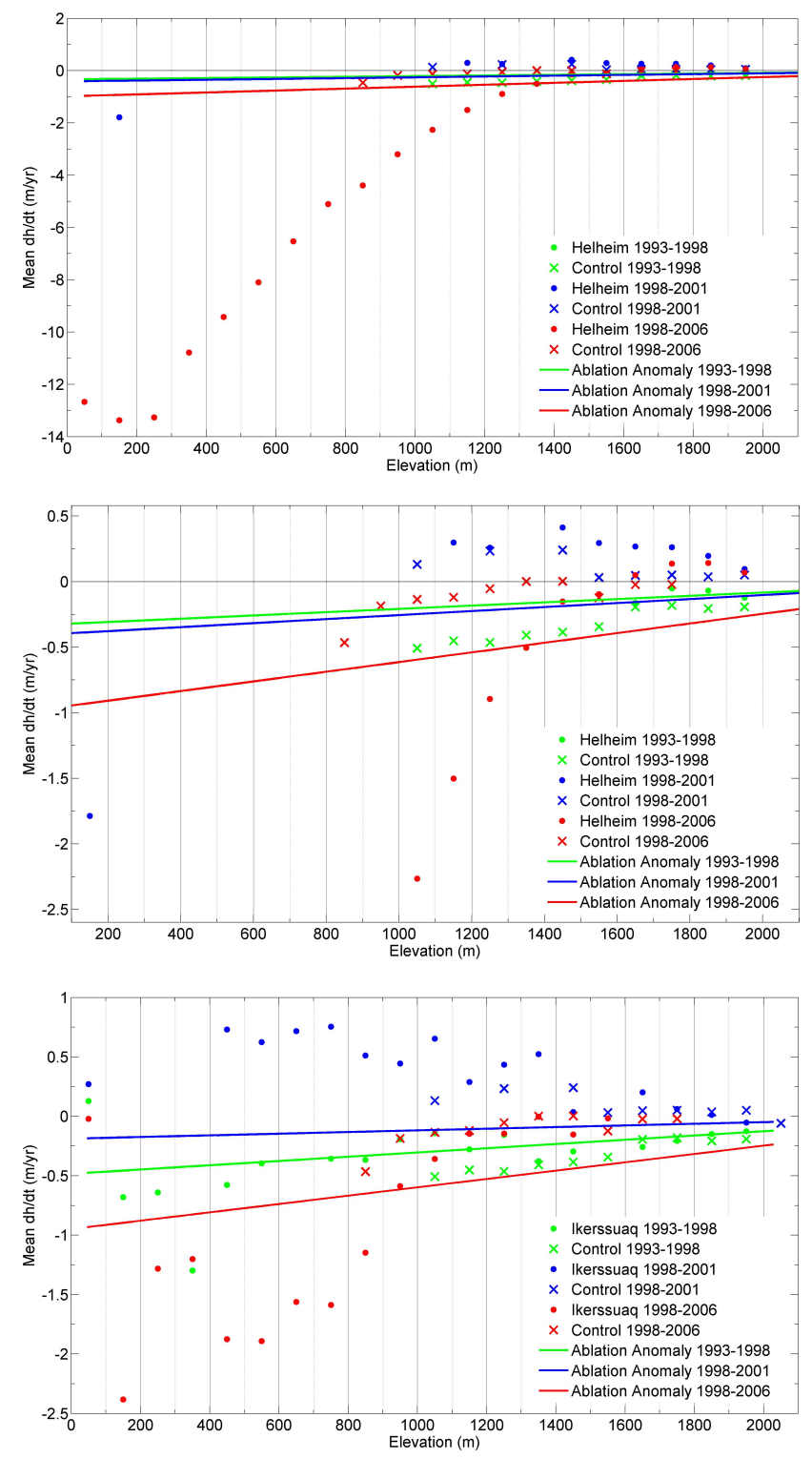

Fig. 2. HG Region. A comparison of surface elevation change rates for Control 1 and (a) HG (b) is a close up of (a); and (c) IG for 1993-1998, 1998-2001 and 1998-2006. Ablation anomalies for the same periods are also shown. These were calculated as described in Sect. 2.4.

Our results are in agreement with those previously published and suggest that ice dynamics play an important role in the peripheral thinning of the ice sheet.

3.2 Hypothesis 2: thinning is principally caused by direct meltwater effects on ice flow: comparing marineterminating and land-terminating outlet glaciers

Surface elevation change rates of marine-terminating and land-terminating outlet glaciers in Southern Greenland were compared for two time periods, from 1993 to 1998 and from

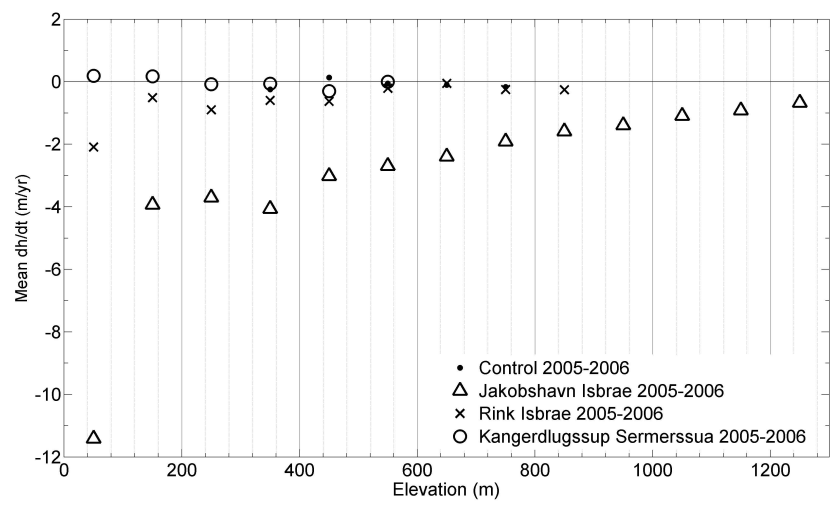

Fig. 3. JI Region. A comparison of surface elevation change rates for Control 2 and JI, RI and KS.

1998 to 2006. The results of these comparisons are shown in Fig. 4 (Table 1) and Fig. 5 (Table 2) respectively. Mean surface elevation change rates were calculated for $100 \mathrm{~m}$ elevation bands and then compared between glaciers.

Between 1993 and 1998, mean $d h / d t$ values for marineterminating outlet glacier thinning ranged from 0.1 to $0.4 \mathrm{~m} \mathrm{yr}^{-1}$ above $1000 \mathrm{~m}$, and from 0.1 to $0.7 \mathrm{~m} \mathrm{yr}^{-1}$ below $1000 \mathrm{~m}$. Mean $d h / d t$ values for land-terminating outlet glaciers range from $0.1 \mathrm{~m} \mathrm{yr}^{-1}$ thinning to $0.1 \mathrm{~m} \mathrm{yr}^{-1}$ thickening above $1000 \mathrm{~m}$ and from $0.25 \mathrm{~m} \mathrm{yr}^{-1}$ thinning to $0.9 \mathrm{~m} \mathrm{yr}^{-1}$ thickening below $1000 \mathrm{~m}$. Below $1000 \mathrm{~m}$ elevation, the difference in mean $d h / d t$ values between marineterminating and land-terminating outlet glaciers is not statistically significant. During this period JI thickened as previously reported (Abdalati et al., 2001; Joughin et al., 2004). If we remove JI from the dataset, the difference in mean $d h / d t$ values becomes significant at the $95 \%$ confidence level. In other words, the majority of marine-terminating outlet glaciers are thinning faster than land-terminating outlet glaciers. There is more variation in $d h / d t$ for marineterminating and land-terminating outlet glaciers at lower elevations, probably due to the movement of crevasses.

For marine-terminating outlet glaciers from 1998 to 2006, $d h / d t$ values vary considerably both within and between elevation bands. Mean $d h / d t$ values range from $\sim 3.0 \mathrm{~m} \mathrm{yr}^{-1}$ thinning between $100 \mathrm{~m}$ to $200 \mathrm{~m}$ elevation to $\sim 0.2 \mathrm{~m} \mathrm{yr}^{-1}$ thinning at $1500 \mathrm{~m}$. The large thinning rates at lower elevations during this time period can to some extent be explained by major retreats of three large marine-terminating outlet glaciers (JI, HG and KG) (See the hollow symbols in Fig. 5 for thinning rates of these individual glaciers). However, the individual data points for marine-terminating outlet glaciers reveal that thinning rates are generally greater across the whole population.

For land-terminating outlets $d h / d t$ values range from $0.14 \mathrm{~m} \mathrm{yr}^{-1}$ thickening to $0.25 \mathrm{~m} \mathrm{yr}^{-1}$ thinning, with no obvious correlation with altitude. The differences between mean thinning values for marine-terminating and 


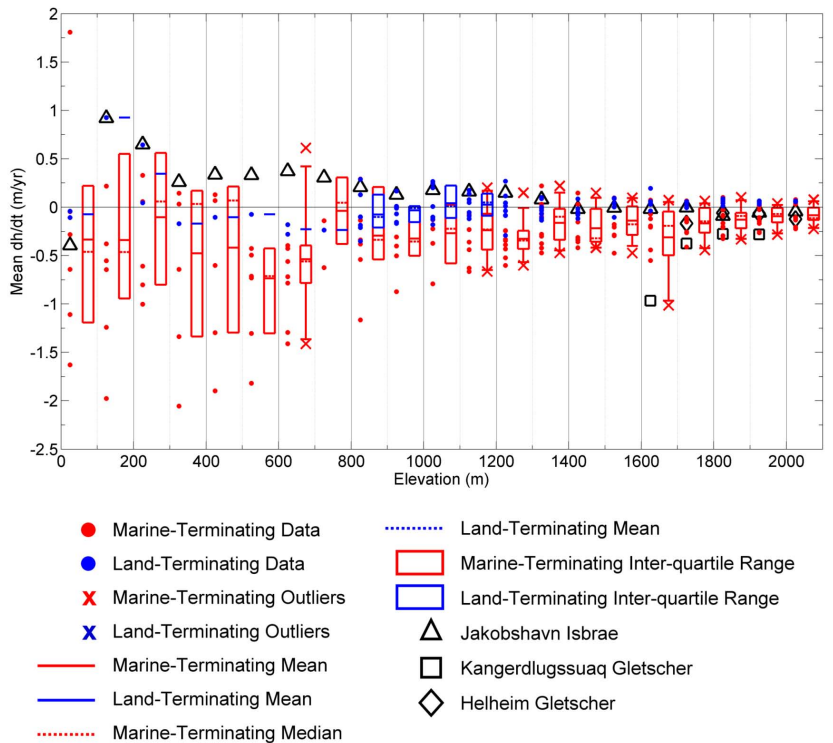

Fig. 4. A comparison of surface elevation change rates for 11 marine-terminating and 6 land-terminating outlet glaciers for the period 1993 to 1998. Marine-terminating outlet glaciers used in this analysis: KS, RI, IG, P, CIV, KG, HG, KNS, QSW, EL and JI. Land-terminating outlet glaciers used in this analysis: SS, RGS, RGN, MAS, MAN and EK (refer to Fig. 1 for locations).

land-terminating glaciers below $1000 \mathrm{~m}$ elevation are significant at the $99.9 \%$ confidence level. Again these differences could be caused solely by the behaviour of H, JI and KG. This is not the case, since if we repeat the analysis with these outlet glaciers removed, the differences are still significant at the $99.9 \%$ confidence level. Thus it seems that marineterminating outlets (as a whole) are behaving very differently to their land-terminating counterparts.

Mean thinning rates for marine-terminating glaciers below $\sim 1000 \mathrm{~m}$ are four times larger (significant at the $99.9 \%$ confidence level) from 1998 to 2006 than from 1993 to 1998. Mean $d h / d t$ values for land-terminating outlets, however, remain statistically unchanged over the same time periods. This suggests that a change in a controlling mechanism specific to the thinning rates of marine-terminating outlet glaciers occurred in the late 1990s and that this change did not affect thinning rates of land-terminating outlet glaciers. Moreover, the statistically significant differences between mean $d h / d t$ values for marine-terminating and land-terminating outlet glaciers suggest that they can be seen as separate populations.

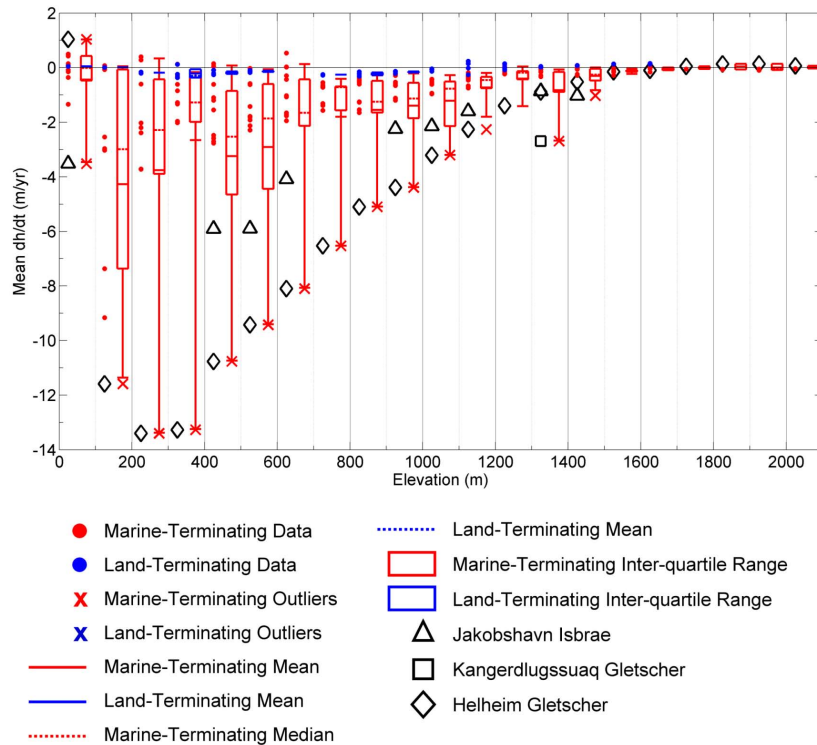

Fig. 5. A comparison of surface elevation change rates for 9 marineterminating and 2 land-terminating outlet glaciers for the period 1998 to 2006. Marine-terminating outlet glaciers used in this analysis: KS, RI, I, CIV, KG, HG, QSW, VG and JI. Land-terminating outlet glaciers used in this analysis: SS and RGS (refer to Fig. 1 for locations).

3.3 Hypothesis 3: thinning on marine-terminating outlet glaciers is due to calving front retreat and thinning on land-terminating ice is due to surface mass balance: comparing observed outlet glacier melt with simulated melt anomalies

The magnitude of observed $d h / d t$ was compared to ablation anomalies calculated as described in Sect. 3.4 the results of which are shown in Fig. 6. The difference between observed $d h / d t$ and $d h / d t$ predicted by the ablation anomalies is hereby referred to as "dynamic" thinning.

The magnitude of "dynamic" thinning of marineterminating outlet glaciers is much larger (mean value of $\sim 5 \mathrm{~m} \mathrm{yr}^{-1}$ at $200 \mathrm{~m}$ elevation) than that of land-terminating outlet glaciers and increases towards the glacier snout. Ice thickness and flux at the termini of land-terminating outlet glaciers are zero, so if integrated across the entire landterminating outlet glacier, any dynamic thinning must be balanced by either thickening in downstream regions, an advance of the ice front, or increased surface melting elsewhere. Land-terminating outlets show little "dynamic" $d h / d t$ (mean of $0.16 \mathrm{~m} \mathrm{yr}^{-1}$ thickening below $1000 \mathrm{~m}$ and standard deviation of 0.25 ) and no obvious relationship between "dynamic" $d h / d t$ and elevation (Fig. 6). Above $1000 \mathrm{~m}$ (the bare ice zone) the PDD model overestimates the amount of thinning for both land and marine-terminating outlet glaciers (shown by positive values in Fig. 6). This is most likely because we assume the DDF at a fixed elevation is constant, whereas in reality its value is likely to vary from year 


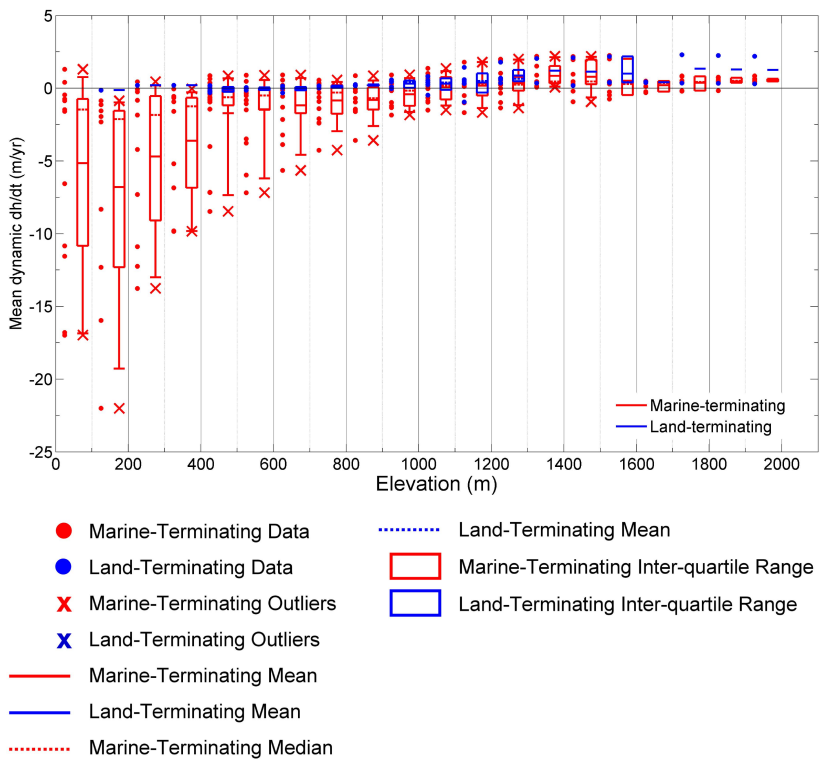

Fig. 6. The magnitude of differences between observed thinning and thinning calculated by a PDD model for all outlet glaciers shown in Fig. 1 and for all years we have data (i.e. not just 1993 to 1998 and 1998 to 2006 ).

to year as firn compaction rates change. At higher elevations, where there is a deep firn layer, surface lowering during summer is mainly caused by evaporation and percolation of surface melt, and the relationship between compaction and air temperature breaks down (Thomas et al., 2003). The PDD model does not include precipitation which may also have an effect (see Sect. 4.2).

Greater thinning of marine-terminating outlet glaciers may represent differences in ice dynamics relative to landterminating outlets rather than suggest an alternative thinning mechanism. Marine-terminating outlets have non-zero ice thickness and flux at their termini, while both quantities approach zero at the margins of land-terminating outlets. If the dynamic draw down of ice scales with flux, a greater and more rapid change in marine-terminating glaciers may be representative of the difference in ice flux rather than indicate calving as the dominant mechanism for marine-terminating thinning. Marine-terminating outlet glaciers are also inherently more sensitive to changes in subglacial water pressure for reasons outlined in Sect. 1.1.

One way of attempting to account for these factors is to examine the percentage of observed thinning which cannot be explained by the thinning predicted by the PDD model (i.e. "dynamic" thinning). This is shown in Fig. 7. Thinning rates in this plot are mean values for every glacier in Fig. 1 for all years that we have survey data (i.e. not just for the periods 1993 to 1998 and 1998 to 2006). For each glacier, only elevation bands which exhibited thinning were included. If observations show thickening, the percentage of observed thinning not explained by the ablation anomaly (which is always negative or zero) cannot be calculated.
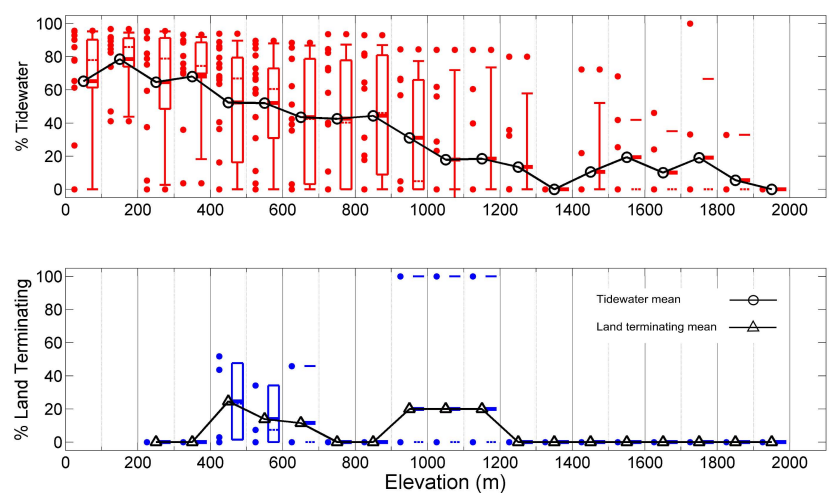

Fig. 7. The percentage of observed thinning which cannot be explained by thinning calculated by a PDD model for all outlet glaciers shown in Fig. 1 for all years with flight lines. A zero $\%$ value means that for all outlet glaciers with data in that particular elevation band, the ablation anomaly thinning was greater than observed thinning.

The percentage of "dynamic" thinning is greater for marine-terminating outlet glaciers and reaches a maximum of $\sim 70 \%$ near the snout. For certain large marineterminating outlet glaciers in recent years, the percentage of total thinning which can be attributed to ice dynamics is likely to be larger than our mean $70 \%$ "dynamic" thinning value (Thomas et al., 2003). This is shown by the individual data points (red dots) in Fig. 7. Our result suggests that at least $75 \%$ of marine-terminating outlet glaciers are experiencing significant dynamic thinning. "Dynamic" thinning of land-terminating outlet glaciers is much lower (mean of $\sim 10 \%$ ). The relatively high percentages between $1000 \mathrm{~m}$ and $1300 \mathrm{~m}$ are caused by a zero melt anomaly for Sarquap Sermia between 1998 and 2001. Temperature time series from Ilulissat show that the late summer of 1999 and mid summer of 2000 were both cooler than those of the normal period (1970 to 2000). If the ablation anomaly is zero, none of the observed thinning can be explained by it and thus all observed thinning is dynamic.

Precipitation can vary by up to $0.6 \mathrm{~m} \mathrm{yr}^{-1}$ in Southern Greenland (Hanna et al., 2006) which is large relative to the $d h / d t$ values for land-terminating outlets. Precipitation data at Tasillaq (which show a good correlation with accumulation, $r=0.75$, for the south eastern region of the ice sheet (Hanna et al., 2006)) show negative anomalies (relative to the 1958 to 2006 mean) for 1998, 1999 and 2000 which could explain the observed changes in surface elevation. See Sect. 4.2 for a more detailed discussion of inter-annual accumulation variability. 


\section{Discussion}

\subsection{Constraint on dynamic thinning}

Our results show that only marine-terminating outlet glaciers display rates of dynamic thinning which differ significantly from thinning predicted by a PDD model, and thus we infer that the main cause of this dynamic thinning depends on those outlet glacier's (and therefore the ice sheet's) direct contact with the ocean.

The GrIS covers an area of about 1.7 million $\mathrm{km}^{2}$. Approximately $300000 \mathrm{~km}^{2}(\sim 18 \%)$ of this ice is grounded below sea level with a large area beneath the ice divide and the remainder mainly in the North of Greenland in the troughs of the major outlet glaciers (Fig. 8). Very few of these coastal subglacial troughs extend more than $100 \mathrm{~km}$ inland (Bamber et al., 2003). In fact, a retreat equivalent to a loss in area of about 2 to $5 \%$ of the entire ice sheet would put the margins out of direct contact with the ocean. The radar data on which this subglacial Digital Elevation Model is based do not resolve deep troughs particularly well (Gogineni et al., 2001). For example, a very narrow deep trough extends 85 to $90 \mathrm{~km}$ inland from Jakobshavn Isfjord connecting JI with at least part of the interior area of below sea level bedrock (Clarke and Echelmeyer, 1996) (red box in Fig. 8). The large distances (greater than $200 \mathrm{~km}$ in most cases), and the occurrence of areas of bedrock above sea level between the inland margins of coastal troughs and the area of ice grounded below sea level beneath the ice divide, mean that there are unlikely to be many other unresolved deep connecting troughs.

Once the ice sheet has retreated inland there will be no calving of ice into the ocean and no melting of submerged ice. Calving is thought to account for about half the total mass loss of the GrIS (Rignot and Kanagaratnam, 2006). Melting of submerged ice in sea water is also an important process where outlets have floating ice tongues. In Northern Greenland, the floating section of Petermans Gletscher is estimated to melt by $\sim 10 \mathrm{~m} \mathrm{yr}^{-1}$, Nioghalvfjerdsbræ Gletscher by $\sim 8 \mathrm{~m} \mathrm{yr}^{-1}$, and Zachariae Isstrøm by $6 \mathrm{~m} \mathrm{yr}^{-1}$ (Rignot et al., 1997). The cessation of these processes would decrease the GrIS's contribution to sea level rise.

It is possible that a retreat would not be uniform and that several deep troughs (such as those in Northern Greenland) may remain in direct contact with the ocean. If this were the case, drawdown of inland ice through dynamic thinning may lower the surface of the ice sheet, leading to a loss in ice volume without much change in area.

4.2 The effect of inter-annual variations in precipitation on presented $d h / d t$

Our PDD calculations of $d h / d t$ do not include the effects of inter-annual variability in accumulation. Snowfall can vary annually by up to $0.6 \mathrm{~m} \mathrm{yr}^{-1}$ in south east Greenland and by up to $0.3 \mathrm{~m} \mathrm{yr}^{-1}$ in south west Greenland (Hanna et

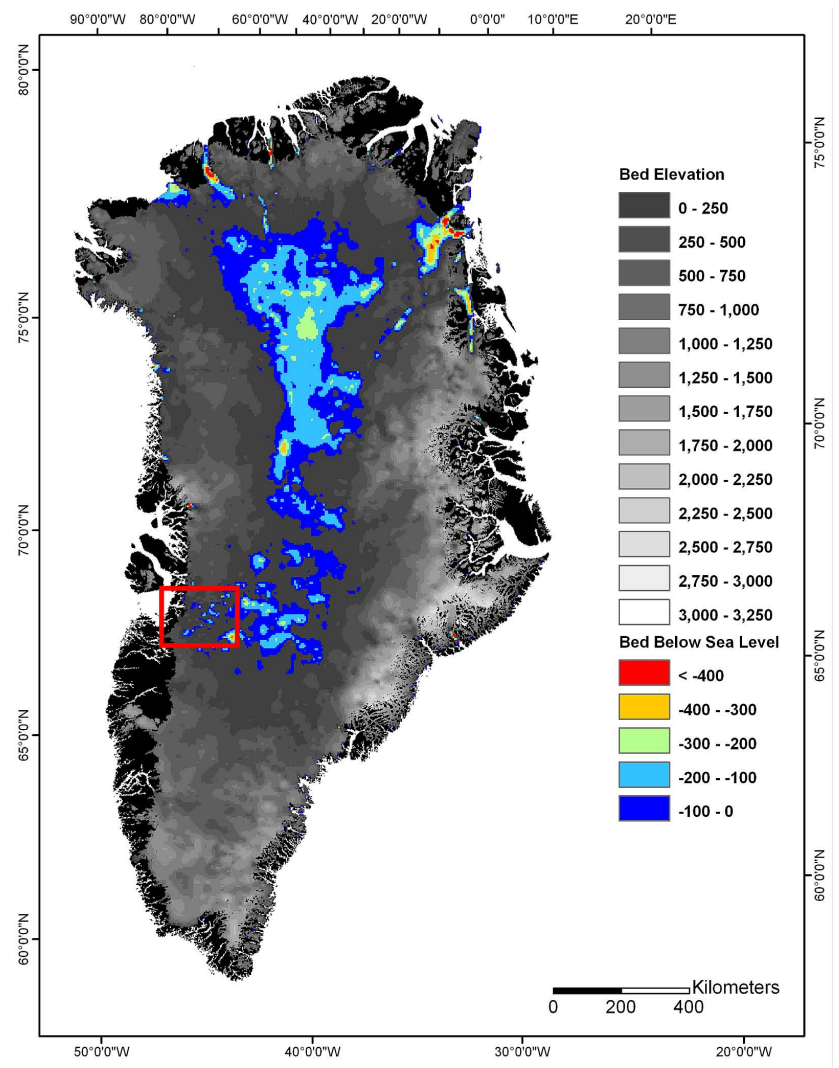

Fig. 8. Present GrIS bed topography from Bamber et al. (2003). The red box delineates the region, mentioned in the text, where a narrow trough extends inland from JI.

al., 2006). Thus, at higher elevations, the differences in surface elevation between 1993 and 1998 and between 1998 and 2006 could be due to variations in snow accumulation rather than or as well as increased ice melt or dynamic thinning.

To assess the importance of inter-annual variations in accumulation to our results, we use modelled (ECMWF ERA-40 reanalysis) accumulation data presented in Hanna et al $(2006,2008)$ for the south east GrIS as well as measured precipitation data from Tasillaq Meteorological Station which correlates well ( $r=0.75$ for five year running means) with accumulation rates for the south east region of the ice sheet (Hanna et al., 2006). The magnitude and inter-annual variation in precipitation for Tasillaq are generally $\sim 20 \%$ greater than for the ERA-40 accumulation for the south east GrIS. The south east GrIS has both the highest absolute precipitation and greatest variability in precipitation of the GrIS (Bales et al., 2001; Hanna et al., 2006, 2008) and so for other regions of the ice sheet, uncertainty due to interannual precipitation variations will also be less.

ERA-40 reanalysis data show that for the south east GrIS, snow accumulation between June 2002 and May 2003 was equivalent to $1.21 \mathrm{~m}$ of water. This is $75 \%$ (3.5 standard deviations) above the mean annual June to May (1959 to 2003) 
accumulation of $0.69 \mathrm{~m}$ (Hanna et al., 2005) and agrees well with laser altimetry measurements of ice thickening for the same period (Krabill et al., 2004). This anomalously high precipitation year could bias our results towards showing less thinning for the south east GrIS from 1998 to 2006. However, the intra-annual effect of the anomaly is probably overshadowed by higher than average numbers of summer PDDs in all years from 1998 to 2006, and by a return to normal precipitation values for the winter of 2003/2004 (Hanna et al., 2006).

Using PDD values from Tasillaq to calculate surface lowering we compared $d h / d t$ for a point with: (a) precipitation anomalies measured at Tasillaq and; (b) zero precipitation for both of our survey periods. We found that including inter-annual variations in precipitation increased the overall surface lowering rate by $0.1 \mathrm{~m} \mathrm{yr}^{-1}$ for both 1993 to 1998 $(0.5 \mathrm{~m})$ and 1998 to $2006(0.8 \mathrm{~m})$. Precipitation decreases inland (Bales et al., 2001; Hanna et al., 2006) in south east Greenland so uncertainty in $d h / d t$ due to precipitation will also decrease away from the coast. Inter-annual variations in accumulation could only affect $d h / d t$ values from 1993 to 1998 and from 1998 to 2006 above $1500 \mathrm{~m}$, where mean land and marine-terminating glacier thinning rates are generally less than $0.25 \mathrm{~m} \mathrm{yr}^{-1}$ (see Figs. 4 and 5).

Below $1500 \mathrm{~m}$ elevation, where differences between mean thinning rates for land-terminating and marine-terminating outlet glaciers are typically $0.5 \mathrm{~m} \mathrm{yr}^{-1}$ for 1993 to 1998 and greater than $5 \mathrm{~m} \mathrm{yr}^{-1}$ for 1998 to 2006, inter-annual precipitation variations are lost in the large thinning rates (see Figs. 4 and 5). Differences between thinning rates of marineterminating outlet glaciers between 1998 to 2006 and 1998 to 2006 are also much larger than the effects of variations in snow accumulation.

The occurrence of a large snowfall event just before a flight could also influence $d h / d t$. Again, using south east GrIS as an example and precipitation data from Tasillaq, we compared the cumulative precipitation before the flights for several glaciers in 1993, 1998 and 2006. For HG, there was a difference of $0.1 \mathrm{~m}$ between 1993 and 1998 flights, and a difference of $0.06 \mathrm{~m}$ between 1998 and 2006 flights. For IG, there was a difference of $0.08 \mathrm{~m}$ between 1993 and 1998 flights and a difference of $0.09 \mathrm{~m}$ between 1998 to 2006 flights. There were no significant $(>30 \mathrm{~mm})$ precipitation events in the 10 days preceding any of the surveys.

\section{Conclusions}

We have confirmed that thinning is greater on outlet glaciers than on neighbouring regions of slow moving ice. Thinning rates of slow moving ice are statistically the same as ablation anomalies simulated by a PDD model. Combined, these results suggest that the majority of the peripheral thinning of the GrIS, as shown in previously published work, is related to ice dynamics.
Although previously reported in the literature for JI, HG and KG (Howat et al., 2005, 2007; Joughin et al., 2004; Krabill et al., 2004; Luckman et al., 2006), our analysis of a large sample of southern GrIS marine and landterminating outlet glacier thinning rates shows that $>75 \%$ of marine-terminating outlet glaciers are thinning significantly more than their land-terminating counterparts. There was a dramatic increase in almost all marine-terminating outlet glacier thinning rates between the periods 1993 to 1998 and 1998 to 2006, suggesting a widespread forcing mechanism. There is no corresponding increase in thinning rates of landterminating outlets. This suggests that a change in a controlling mechanism specific to the thinning rates of marineterminating outlet glaciers occurred in the late 1990s and that this change did not affect thinning rates of land-terminating outlet glaciers.

Thinning rates of marine-terminating outlet glaciers are not statistically the same as ablation anomalies, while thinning rates of land-terminating outlet glaciers are statistically identical. In other words, we see no widespread thinning (greater than that expected from enhanced ablation) of landterminating margins of the ice sheet suggesting that basal lubrication is not at present significantly influencing the thinning rates of land-terminating outlet glaciers. We have shown that these differences are not simply due to large marineterminating outlet glaciers such as JI, HG and KG weighting the mean values in favour of thinning (see individual data points in Fig. 5).

The mean (for all marine-terminating glaciers and all years for which $d h / d t$ data is available) percentage of total thinning not attributable to enhanced ablation (i.e. "dynamic" thinning) is greater for marine-terminating outlet glaciers and increases down-glacier to a maximum of $\sim 70 \%$ near the calving front. The percentage of total thinning which can be attributed to ice dynamics is likely to be larger than our mean $70 \%$ value for certain marine-terminating outlet glaciers (Thomas et al., 2003) as shown by the individual data points (red dots) in Fig. 7. For land-terminating outlet glaciers, "dynamic" thinning is responsible for $\sim 10 \%$ of observed thinning, and shows no obvious correlation with elevation.

In agreement with previously published results (Abdalati et al., 2001; Howat et al., 2005, 2007; Joughin et al., 2008b; Krabill et al., 2004; Thomas, 2004; Thomas et al., 2003) we suggest that thinning of land-terminating outlet glaciers is principally controlled by variations in local mass balance, while thinning of marine-terminating outlet glaciers is more dependent on ice dynamics. The mechanism by which this dynamic thinning occurs is still not clear although a good correlation between calving front retreat and thinning rates (Joughin et al., 2008b) suggests that perturbations at the termini of marine-terminating outlet glaciers are mainly responsible. Force balance analyses of both floating (Thomas, 2004) and grounded (Howat et al., 2005) termini confirm calving as the dominant process in the retreat and 
acceleration of JI and $\mathrm{HG}$ and $\mathrm{KG}$.

Dynamic thinning related to calving will cease once the ice sheet retreats beyond the direct influence of the ocean. These findings will help to focus future efforts to understand the principal causes of rapid ice sheet change.

Edited by: G. H. Gudmundsson

\section{References}

Abdalati, W., Krabill, W., Frederick, E., Manizade, S., Martin, C., Sonntag, J., Swift, R., Thomas, R., Wright, W., and Yungel, J.: Outlet glacier and margin elevation changes: Near coastal thinning of the Greenland ice sheet, J. Geophys. Res., 106, 3372933741, 2001.

Abdalati, W. and Steffen, K.: Snowmelt on the Greenland Ice Sheet as derived from passive microwave satellite data, J. Climate, 10, 165-175, 1997.

Alley, R., Dupont, T., Parizek, B., and Anandakrishnan, S.: Access of surface meltwater to beds of sub-freezing glaciers: preliminary insights, Ann. Glaciol., 40, 8-14, 2005.

Bales, R., McConnell, J., Mosely-Thompson, E., and Csatho, B.: Accumulation over the Greenland ice sheet from historical and recent records, J. Geophys. Res., 106, 33813-33825, 2001.

Bamber, J., Alley, R., and Joughin, I.: Rapid response of modern day ice sheets to external forcing, Earth Planet. Sc. Lett., 257, 1-13, 2007.

Bamber, J., Baldwin, D., and Gogineni, P.: A new bedrock and surface elevation dataset for modelling the Greenland ice sheet, Ann. Glaciol., 37, 351-356, 2003.

Bamber, J., Hardy, R., and Joughin, I.: An analysis of balance velocities over the Greenland ice sheet and comparison with synthetic aperture radar interferometry, J. Glaciol., 46, 67-74, $2000 \mathrm{~b}$.

Bingham, R., Nienow, P., Sharp, M., and Boon, S.: Subglacial drainage processes at a High Arctic polythermal valley glacier, J. Glaciol., 51, 15-24, 2005.

Boon, S. and Sharp, M.: The role of hydrologically-driven ice fracture in drainage system evolution on an Arctic glacier, Geophys. Res. Lett., 30, 1916, doi:10.1029/2003GL018034, 2003.

Box, J. and Ski, K.: Remote sounding of Greenland supraglacial melt lakes: implications for subglacial hydraulics, J. Glaciol., 53, 257-265, 2007.

Braithwaite, R.: Positive degree-day factors for ablation on the Greenland ice sheet studied by energy-balance modelling, J. Glaciol., 41, 153-160, 1995.

Cappelen, J., Jorgensen, B., Laursen, E., Stannius, L., and Thomsen, R.: The observed climate of Greenland, 1961-1999 with climatological standard normals, 1961-1990, DMI Technical Report 00-18, 2001.

Cappelen, J., Laursen, E., and Kern-Hansen, C.: DMI Daily Climate Data Collection 1873-2006, Denmark, The Faroe Islands and Greenland-including Air Pressure Observations 1874-2006 (WASA Data Sets), DMI Technical Report 07-07, Copenhagen, 2007.

Clarke, T. and Echelmeyer, K.: Seismic-reflection evidence for a deep subglacial trough beneath Jakobshavn Isbrae, West Greenland, J. Glaciol., 42, 219-232, 1996.
Dall'amico, M. and Hornsteiner, M.: A simple method for estimating daily and monthly mean temperatures from daily minima and maxima, Int. J. Climatol., 26, 1929-1936, 2006.

Das, S. B., Joughin, I., Behn, M., Howat, I., King, M. A., Lizarralde, D., and Bhatia, M. P.: Fracture Propagation to the Base of the Greenland Ice Sheet During Supraglacial Lake Drainage, Science, 320, 778-781, 2008.

Echelmeyer, K. and Harrison, W.: Jakobshavn Isbrae, West Greenland, seasonal variations in velocity-or lack thereof, J. Glaciol., 36, 82-88, 1990.

Ekstrom, G., Nettles, M., and Tsai, V.: Seasonality and Increasing Frequency of Greenland Glacial Earthquakes, Science, 311, 1756-1758, 2006.

Fettweis, X., van Ypersele, J., Gallee, H., Lefebre, F., and Lefebrve, W.: The 1979-2005 Greenland ice sheet melt extent from passive microwave data using an improved version of the melt retrieval XPGR algorithm, Geophys. Res. Lett., 34, L05502, doi:10.1029/2006GL028787, 2007.

Funk, M., Echelmeyer, K., and Iken, A.: Mechanisms of fast flow in Jakobshavn Isbrae, west Greenland: Part ii, Modelling of englacial temperatures, J. Glaciol., 40, 569-585, 1994.

Gogineni, S., Tammana, D., Braaten, D., Leuschen, C., Akins, T., Legarsky, J. L., Kanagaratnam, P., and Stiles, J.: Coherent radar ice thickness measurements over the Greenland Ice Sheet, J. Geophys. Res., 106, 33761-33772, 2001.

Hanna, E., Huybrechts, P., Janssens, I., Cappelen, J., Steffen, K., and Stephens, A.: Runoff and mass balance of the Greenland ice sheet: 1958-2003, J. Geophys. Res., 110, D13108, doi:10.1029/2004JD005641, 2005.

Hanna, E., Huybrechts, P., Steffen, K., Cappelen, J., Huff, R., Shuman, C., Irvine-Fynn, T., Wise, S., and Griffiths, M.: Increased runoff from melt from the Greenland Ice Sheet: A response to global warming, J. Climate, 21, 331-341, 2008.

Hanna, E., McConnell, J., Das, S. B., Cappelen, J., and Stephens, A.: Observed and Modeled Greenland Ice Sheet Snow Accumulation, 1958-2003, and Links with Regional Climate Forcing, J. Climate, 19, 344-358, 2006.

Hanna, E. and Valdes, P.: Validation of ECMWF (re)analysis surface climate data, 1979-1998, for Greenland and implications for mass balance modelling of the ice sheet, Int. J. Climatol., 21, 171-195, 2001.

Howat, I., Joughin, I., and Scambos, T.: Rapid Changes in Ice Discharge from Greenland Outlet Glaciers, Science, 315, 15591561, 2007.

Howat, I., Joughin, I., Tulaczyk, S., and Gogineni, S.: Rapid retreat and acceleration of Helheim glacier, east Greenland, Geophys. Res. Lett., 32, L22502, doi:10.1029/2005GL024737, 2005.

Joughin, I., Abdalati, W., and Fahenstock, M.: Large fluctuations in speed on Greenlands Jakobshavn Isbrae glacier, Nature, 432, 608-610, 2004.

Joughin, I., Das, S., King, M., Smith, B., Howat, I., and Moon, T.: Seasonal Speedup Along the Western Flank of the Greenland Ice Sheet, Science, 320, 781-783, 2008a.

Joughin, I., Howat, I., Alley, R., Ekstrom, G., Fahenstock, M., Moon, T., Nettles, M., Truffer, M., and Tsai, V.: Ice-Front Variation and Tidewater Behavior on Helheim and Kangerdlugssuaq Glaciers, Greenland, J. Geophys. Res., 113, F01004, doi:10.1029/2007JF000837, 2008b.

Joughin, I., Tulaczyk, S., Fahnestock, M., and Kwok, R.: A mini 
surge on the Ryder glacier, Greenland, observed by satellite radar interferometry, Science, 274, 228-230, 1996.

Kamb, B.: Glacier surge mechanism based on linked cavity configuration of the basal water conduit system, J. Geophys. Res., 92, 9083-9100, 1987.

Krabill, W., Abdalati, W., Frederick, E., Manizade, S., Martin, C., Sonntag, J., Swift, R., Thomas, R., Wright, W., and Yungel, J.: Greenland ice sheet: High elevation balance and peripheral thinning, Science, 289, 428-430, 2000.

Krabill, W., Frederick, E., Manizade, S., Martin, C., Sonntag, J., Swift, R., Thomas, R., Wright, W., and Yungel, J.: Rapid thinning of parts of the Southern Greenland ice sheet, Science, 283, 1522-1524, 1999.

Krabill, W., Hanna, E., Huybrechts, P., Abdalati, W., Cappelen, J., Csatho, B., Frederick, E., Manizade, S., Martin, C., Sonntag, J., Swift, R., Thomas, R., and Yungel, J.: Greenland ice sheet: Increased coastal thinning, Geophys. Res. Lett., 31, L24402, doi:10.1029/2004GL021533, 2004.

Luckman, A., Murray, T., de Lange, R., and Hanna, E.: Rapid and synchronous ice-dynamics changes in East Greenland, Geophys. Res. Lett., 33, L03503, doi:10.1029/2005GL022519, 2006.

Luthi, M., Funk, M., Iken, A., Gogineni, S., and Truffer, M.: Mechanisms of fast flow in Jakobshavn Isbrae, west Greenland: Part iii, Measurements of ice deformation, temperature and cross borehole conductivity in boreholes to the bedrock, J. Glaciol., 48, 369-385, 2002

Mair, D., Nienow, P., Willis, I., and Sharp, M.: Spatial patterns of glacier motion during a high-velocity event: Haut Glacier d'Arolla, Switzerland, J. Glaciol., 47, 9-20, 2001.

McMillan, M., Nienow, P., Shepherd, A., Benham, T., and Sole, A.: Seasonal evolution of supra-glacial lakes on the Greenland Ice Sheet, Earth Planet. Sc. Lett., 262, 484-492, 2007.

Meier, M. and Post, A.: Fast Tidewater Glaciers, J. Geophys. Res., 92, 9051-9058, 1987.

Parizek, B. and Alley, R.: Implications of increased Greenland surface melt under global-warming scenarios: ice sheet simulations, Quaternary Sci. Rev., 23, 1013-1027, 2004.

Payne, A., Vieli, A., Shepherd, A., Wingham, D., and Rignot, E.: Recent dramatic thinning of largest West Antarctic ice stream triggered by oceans, Geophys. Res. Lett., 31, L23401, doi:10.1029/2004GL021284, 2004.
Rignot, E., Braaten, D., Gogineni, S., Krabill, W., and McConnell, J.: Rapid ice discharge from southeast Greenland glaciers, Geophys. Res. Lett., 31, L10401, doi:10.1029/2004GL019474, 2004.

Rignot, E., Gogineni, S., Krabill, W., and Ekholm, S.: North and North East Greenland Ice Discharge from Satellite Radar Interferometry, Science, 276, 934-937, 1997.

Rignot, E. and Kanagaratnam, P.: Changes in the velocity structure of the Greenland Ice Sheet, Science, 311, 986-990, 2006.

Schmeltz, M., Rignot, E., Dupont, T., and MacAyeal, D.: Sensitivity of Pine Island Glacier, West Antarctica, to changes in iceshelf and basal conditions, J. Glaciol., 48, 552-558, 2002.

Sneed, W. and Hamilton, G.: Evolution of melt pond volume on the surface of the Greenland Ice Sheet, Geophys. Res. Lett., 34, L03501, doi:10.1029/2006GL028697, 2007.

Tedesco, M.: Snowmelt over the Greenland and Antarctica ice sheets from spaceborne radiometric data: extreme events and updated trends, Eos Trans. AGU, 88(52), Fall Meet. Suppl., Abstract C12A-04, 2007.

Thomas, R.: Force-perturbation analysis of recent thinning and acceleration of Jakobshavn Isbrae, Greenland, J. Glaciol., 50, 5766, 2004.

Thomas, R., Abdalati, W., Frederick, E., Krabill, W., Manizade, S., and Steffen, K.: Investigation of surface melting and dynamic thinning on Jakobshavn Isbrae, Greenland, J. Glaciol., 49, 231239, 2003.

Truffer, M., Harrison, W., and March, R.: Record negative glacier balances and low velocities during the 2004 heatwave in Alaska, USA: implications for the interpretation of observations by Zwally and others in Greenland, J. Glaciol., 51, 663-664, 2005.

van der Veen, C.: Calving Glaciers, Prog. Phys. Geog., 26, 96-122, 2002.

van der Veen, C.: Fracture propagation as means of rapidly transferring surface meltwater to the base of glaciers, Geophys. Res. Lett., 34, L01501, doi:10.1029/2006GL028385, 2007.

Zwally, H., Abdalati, W., Herring, T., Larson, K., Saba, J., and Steffen, K.: Surface melt-induced acceleration of Greenland ice sheet flow, Science, 297, 218-222, 2002. 